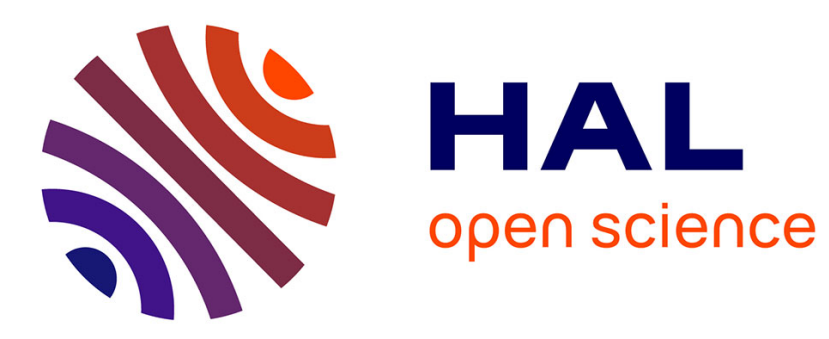

\title{
Competition and Decentralisation in Government Bureaucracies
}

\author{
Maija Halonen-Akatwijuka, Carol Propper
}

\section{To cite this version:}

Maija Halonen-Akatwijuka, Carol Propper. Competition and Decentralisation in Government Bureaucracies. Journal of Economic Behavior and Organization, 2008, 67 (3-4), pp.903. 10.1016/j.jebo.2007.08.009 . hal-00614684

\section{HAL Id: hal-00614684 \\ https://hal.science/hal-00614684}

Submitted on 15 Aug 2011

HAL is a multi-disciplinary open access archive for the deposit and dissemination of scientific research documents, whether they are published or not. The documents may come from teaching and research institutions in France or abroad, or from public or private research centers.
L'archive ouverte pluridisciplinaire HAL, est destinée au dépôt et à la diffusion de documents scientifiques de niveau recherche, publiés ou non, émanant des établissements d'enseignement et de recherche français ou étrangers, des laboratoires publics ou privés. 


\section{Accepted Manuscript}

Title: Competition and Decentralisation in Government Bureaucracies

Authors: Maija Halonen-Akatwijuka, Carol Propper

PII: $\quad$ S0167-2681(07)00200-4

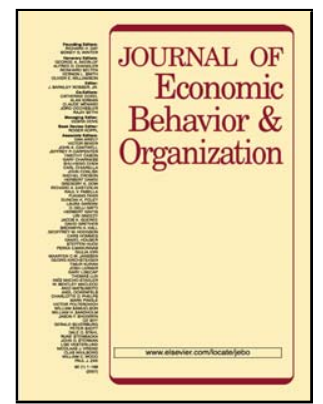

DOI: $\quad$ doi:10.1016/j.jebo.2007.08.009

Reference: $\quad$ JEBO 2151

To appear in: Journal of Economic Behavior \& Organization

Received date: $\quad$ 1-2-2006

Revised date: 29-3-2007

Accepted date: $\quad 16-8-2007$

Please cite this article as: Halonen-Akatwijuka, M., Propper, C., Competition and Decentralisation in Government Bureaucracies, Journal of Economic Behavior and Organization (2007), doi:10.1016/j.jebo.2007.08.009

This is a PDF file of an unedited manuscript that has been accepted for publication. As a service to our customers we are providing this early version of the manuscript. The manuscript will undergo copyediting, typesetting, and review of the resulting proof before it is published in its final form. Please note that during the production process errors may be discovered which could affect the content, and all legal disclaimers that apply to the journal pertain. 


\title{
Competition and Decentralisation in Government Bureaucracies
}

\author{
Maija Halonen-Akatwijuka and Carol Propper \\ Department of Economics \\ University of Bristol
}

March 2007

Corresponding author

Carol Propper

Department of Economics

University of Bristol

8 Woodland Road

Bristol BS8 1TN, UK

Carol.Propper@bristol.ac.uk

Acknowledgements

We would like to thank Guido Friebel, Paul Grout and Ben Lockwood and a very helpful referee for their comments as well as seminar audiences at Barcelona, Bristol, Exeter, IFS, Southampton and York. 


\title{
Competition and Decentralisation in Government Bureaucracies
}

\author{
Maija Halonen-Akatwijuka ${ }^{1}$ and Carol Propper \\ University of Bristol and CMPO
}

August 2007

${ }^{1}$ Corresponding author. We would like to thank Guido Friebel, Paul Grout and Ben Lockwood and a very helpful referee for their comments as well as seminar audiences at Barcelona, Bristol, Exeter, IFS, Southampton and York. 


\begin{abstract}
Recent reforms to the provision of welfare services by the public sector have transferred control rights in production from politicians to managers and simultaneously introduced competition between public sector suppliers. We derive conditions under which a self-interested politician will introduce either competition and/or managerial control for services where quality matters. We show that both competition and managerial control give incentives for greater managerial effort. However the cost of competition is higher taxes and the cost of decentralisation is a loss of political benefits. The politician will introduce these reforms if the political benefits from higher value service outweigh these costs.
\end{abstract}




\section{Introduction}

Privatisation is not the only way governments have sought to increase the efficiency of the public sector. Politicians have also attempted reform within government, particularly of state-provided welfare services such as health care, housing and education. One model is the creation of a separate agency within government whose sole task is to administrate a single, clearly defined program. A more radical option, recently pursued by several governments, is the devolution of decision making to local level coupled with the creation of competing provider organisations within the public sector.

Analysis of reforms that allow competition within the state sector is of considerable interest. This type of reform has been widely adopted in the UK welfare state, where it known as 'quasi-market' reform (Le Grand 1991), and it is not uncommon in the US, where it is referred to as an 'internal market' and is a model that has received considerable interest from other governments who both engage in the provision and funding of welfare services. Examples in UK include the quasi-market reforms in health care, education, social services, and social rented housing. Examples elsewhere are primarily reform of the provision of health care. These quasi-market reforms combine tax finance of (and in many cases, universal entitlement to) a service with competition between publicly financed suppliers.

Privatisation can be defined as a combination of the reallocation of control rights from politicians to managers (corporatisation) and an increase in cash-flow ownership of managers and private investors (Boycko et al 1996 and Shleifer and Vishny 1994). Privatised enterprises may operate in markets with or without competition. The reforms of publicly provided welfare services such as health care and education can be similarly classified according to whether control rights are transferred from politicians to managers, whether there is change of ownership of cash flows, and whether there is competition in supply. In the cases of an agency or competition between suppliers who are within the public sector, managers are given greater control rights but ownership of cash flows remains with the government. These reforms are therefore the equivalent of corporatisation. The two cases differ in that in the latter multiple agencies are created to fulfill the task and are intended to compete with each other. Where government privatises the services (for example, in the case of prisons in some US states and in the UK) there is change in ownership of cash flows on top of transfer of control rights to managers and competition (either for the contract or in supply). 
This paper analyses the conditions under which a self-interested politician would introduce competition within suppliers located in the public sector (i.e. would introduce quasi-market reforms). We separate the dimensions of control rights and competition in supply. Control rights may be given to managers or retained by politicians. Competition may or may not be introduced. We assume universal entitlement and focus on the impact of such reforms on the quality of the service.

We assume competition on the supply side is characterised by small numbers, reflecting the local nature of public services. We determine which form of production a self-interested politician would choose using an incomplete contracting approach. The politician designs the organisation of public services to maximise his own utility. He derives a political benefit from highvalue service since voters like it, but has to raise taxes to pay for it, which voters do not like. We assume the manager derives private benefits from service production, but these are lower when she does not have control rights.

We show that the politician can use the instruments of managerial control and competition to elicit greater managerial effort and, hence, higher quality of public services. However, managerial control and higher quality come at a cost: the first brings a loss of political benefits, the second higher tax revenues. The politician will choose competition when he derives benefit from a high-value service and when cost of raising taxes is not too high. He will delegate control rights if the effort level that can be implemented under managerial control is sufficiently greater than under politician control, outweighing the loss of political benefit to him of being fully in charge of the service. In the choice of organisational form, there is a trade-off between popularity of the service being provided and the relative private benefit that the manager and politician get respectively from being seen as associated with the service. Our analysis also shows that delegation is not always optimal when the supplier gets more private benefit from service provision, and competition may be introduced even when managers have strong private incentives to supply high quality services.

Our paper follows the literature on privatisation by focusing on the issues of control rights and competition. Boycko et al (1996), Hart et al (1997), and Shleifer and Vishny (1994) have used an incomplete contracting approach to analyse privatisation, and it has been suggested that this would be a fruitful way to look at government organisation (Tirole (1994)). We allow for an explicit role for the politician in choosing the form that service delivery should take. Recent literature on public services has examined the role of 
agent motivation (e.g. Besley and Ghatak 2005) and Francois 2000) and in keeping with this literature we assume that both service providers and politicians get non-monetary benefits from service provision.

The organisation of this paper is as follows. In Section 2 we present the institutional details of one particular set of quasi-market reforms: those in the UK. In Section 3 we present the model. In Section 4 we analyse the various organisational forms. Section 5 examines the forces determining the optimal organisation. Section 6 examines the sensitivity of the results to a change in key parameters. The final section discusses the applicability of the model.

\section{The Institutional Details: the UK Quasi- Market Reforms}

Prior to the late 1980s the in-kind benefits, health care, education, social services and social rented housing, of the UK (and other European welfare states) were funded through taxation and delivered by service providers who were part of either a central or a local government department. Each service provider was responsible for all services delivered in a local region. Service users had little choice of provider. Standards for provision (mainly in terms of inputs) were determined by the central government ministry responsible for provision of the service (sometimes with some local political control).

Such arrangements were criticised for being unresponsive to users, and inefficient and different models of service delivery were sought. One model was to contract out services completely to private providers (Szymanski and Bello 1996). Another was to introduce competition on the supply side within the public sector whilst maintaining tax finance. These so-called 'quasimarket' reforms maintained tax finance, but changed the form of service provider and separated funding and provision.

We describe here the current UK set up. In each service, the reforms created organisations responsible for the purchase of the service. These purchasers are allocated tax funds on the basis of need (primarily demographic characteristics). Purchasers buy the relevant service for all users who fall within their geographical jurisdiction. They are not restricted in their choice of supplier, introducing the incentive of competition for suppliers (in some cases the suppliers can include the private sector). 
The previous monopoly suppliers were broken up into stand-alone entities operating within the public sector. Their funding no longer comes directly from the central ministry or local government, but is determined by contracts won from purchasers. The importance of geographical access means this is generally between a limited number of providers. Managers of suppliers have been given greater control rights. Direct local political control of suppliers has been reduced, and politicians stress that the responsibility for local services rests with local purchasers and providers. But while management have been given greater control rights over inputs, outputs, and pay, the ownership of the suppliers' physical assets remains in the public sector. Managers are subject to central ministry scrutiny of investment decisions and control on access to capital markets. Control over cash flows between financial years is retained by central government. These public suppliers are not allowed to carry forward savings between financial years without central ministry approval and are generally required to break-even each year (Le Grand and Bartlett 1993 and Propper 1996). These reforms therefore can be viewed as similar to the corporatisation element of privatisation programmes: ownership of the asset remains with the government, but managers have greater control rights.

In all these services quality of service is important to the user, and in introducing the quasi-market reforms, politicians in the UK stressed that one aim is to increase the responsiveness of the service to the needs of users. Quality is also an aim of the producers of the service, as suppliers are composed of groups of professionals (physicians, nurses, teachers) with professional norms that stress quality.

In this paper we focus on the supply side of the quasi-market reforms. We do not model the aims of purchasers; we assume their only role is to buy the highest quality services using tax financed funds. Starting from a position of no competition and political control rights (the departmental administration form of service provision), a politician may introduce reform of the public sector. This reform may either be to introduce competition and/or shift control rights. Where competition is deemed to be possible, the politician may choose either to give the managers control rights or to retain them. The options open to the politician can be mapped into a $2 \times 2$ matrix of four cells. These are given in Table 1. A traditional central government department is in the no-competition, political control rights cell. Quasi-market reforms are located in the competition, managerial control rights cell. The single agency is in the no-competition, managerial control cell. Below we put forward a 
very specific definition of the political control rights-competition cell, but in a more general framework this cell could be seen as competition between very heavily regulated government providers.

\section{The Model}

The key players in the model are a politician $(\mathrm{P})$ and two suppliers of services, each run by a manager $(\mathrm{M})^{1}$. All are risk neutral. The quality of service is not verifiable (though it is observable). The politician selects the institutional arrangements for service delivery that maximises his own utility. ${ }^{2}$

Each supplier has a capacity of one unit. The value of the supplier's service is stochastic and depends upon the unobservable effort of the manager. The value is

$$
\begin{cases}\bar{v} & \text { with probability } p\left(e_{i}\right) \\ \underline{v} & \text { with probability }\left(1-p\left(e_{i}\right)\right)\end{cases}
$$

where $0 \leq \underline{v}<\bar{v}$, and $e_{i}$ is the effort of the manager. Denote $\Delta v \equiv(\bar{v}-\underline{v})$. The expected value of the service is then $v_{i}=\underline{v}+p\left(e_{i}\right) \triangle v \cdot c\left(e_{i}\right)$ is the cost of effort to the manager. We make standard assumptions about the probability and cost functions.

Assumption 1. $e_{i} \in[0, E]$ where $E>0 . p(0) \geq 0$ and $p(E)<1 . p^{\prime}\left(e_{i}\right)>$ 0 and $p^{\prime \prime}\left(e_{i}\right)<0 . c(0)=0 . c^{\prime}\left(e_{i}\right)>0$ and $c^{\prime \prime}\left(e_{i}\right)>0$ for $e_{i} \in(0, E)$ with $\lim _{e_{i} \rightarrow 0} c^{\prime}\left(e_{i}\right)=0$ and $\lim _{e_{i} \rightarrow E} c^{\prime}\left(e_{i}\right)=\infty$.

The demand for the service is two units with probability $\lambda$ and one unit with probability $(1-\lambda)$. This demand structure is a device to model competition for the suppliers rather than a treatment of stochastic demand at system level. When demand is one unit there is Bertrand competition between the suppliers, while when the demand is two units the suppliers do not compete because a supplier can only produce one unit. $\lambda$ is then the (inverse of) the degree of competition. We assume that competition is not too tough: $\lambda \geq \underline{\lambda}$ where $0<\underline{\lambda}<1$.

\footnotetext{
${ }^{1}$ The two managers are identical ex ante, so in our exposition we do not explicitly subscript the managers except where necessary.

${ }^{2}$ We assume monetary transfers (bribes) between politicians and managers are illegal and unenforceable, so we do not examine joint surplus maximising structures.
} 
The politician $(\mathrm{P})$ gets a noncontractible political benefit, $P\left(v_{1}+v_{2}\right)$, which depends on the value of the service. ${ }^{3}$ We assume $P$ is increasing in $\left(v_{1}+v_{2}\right)$, on the grounds that if the value is low the politician may lose the next election. But the politician also has to raise taxes, $T$, to pay for the services, which has a cost $D(T)$. Part of the cost arises from distortions in the economy caused by taxes while part is political: voters do not like high taxes. We assume benefit and costs are such that

Assumption 2. $P\left(v_{1}+v_{2}\right)=\rho\left(v_{1}+v_{2}\right)$ where $\rho$ is positive. $D(T) \geq 0$. $D^{\prime}(T)>0$ and $D^{\prime \prime}(T)>\underline{D}$ where $\underline{D}>0$.

$\mathrm{P}$ has two choices: implement competition or not, delegate control rights or not. This leads to four organisational structures: $(i)$ no competition and $\mathrm{P}$ control, (ii) no competition and $\mathrm{M}$ control, ( $i i i)$ competition and $\mathrm{P}$ control and ( $i v)$ competition and $\mathrm{M}$ control. To model the arms' length nature of competition within the public sector, we assume under competition $\mathrm{P}$ chooses between suppliers, but cannot fire the manager except by not buying from the supplier. ${ }^{4}$ Under no competition (the traditional bureaucratic hierarchy), $\mathrm{P}$ controls the suppliers directly and has the right to fire the manager.

The benefits of $\mathrm{P}$ and $\mathrm{M}$ depend on whether they have the control rights. The actors who have the control rights gets higher benefits from service provision, on the grounds that they are seen by users (who are also voters) as being more associated with service delivery. If $\mathrm{P}$ has the control rights his political benefit from service delivery is $P\left(v_{1}+v_{2}\right)$.Under managerial control his political benefits are reduced to $\alpha_{P} P\left(v_{1}+v_{2}\right)$, where $0 \leq \alpha_{P} \leq 1$.

We also assume that $M$ gets a private benefit from the value of the service. M's private benefit is $B\left(v_{i}\right)$ when $\mathrm{M}$ has control rights but is $\alpha_{M} B\left(v_{i}\right)$, where $0 \leq \alpha_{M} \leq 1$, when the control rights belong to the politician. We assume that M's private benefit is $B\left(v_{i}\right)=\beta v_{i}$ where $\beta>0$.

Both $\alpha_{P}$ and $\alpha_{M}$ are exogenous. We assume these parameters come from information and reputation and reflect the fact that both $\mathrm{P}$ and $\mathrm{M}$ get less credit if not fully associated with a project.

The agent with the control rights chooses the manager's wages, $w_{i}$. We assume for simplicity that the outside wage for the manager is equal to zero.

\footnotetext{
${ }^{3}$ Our results are robust to alternative specification for political benefits $P\left(\lambda\left(v_{1}+v_{2}\right)+(1-\lambda) \max \left\{v_{1}, v_{2}\right\}\right)$.

${ }^{4}$ This set up is intended to capture the impact of introducing competition by creating a purchaser function. We do not analyse the role of the purchaser as it complicates the analysis without adding insight.
} 
Given the above, the politician's utility is

$$
U= \begin{cases}\rho\left(v_{1}+v_{2}\right)-D(T) & \text { if } \mathrm{P} \text { has control rights } \\ \alpha_{P} \rho\left(v_{1}+v_{2}\right)-D(T) & \text { if } \mathrm{M} \text { has control rights }\end{cases}
$$

and the manager's utility is:

$$
U_{M}= \begin{cases}\beta v_{i}+w_{i}-c\left(e_{i}\right) & \text { if } \mathrm{M} \text { has control rights } \\ \alpha_{M} \beta v_{i}+w_{i}-c\left(e_{i}\right) & \text { if } \mathrm{P} \text { has control rights }\end{cases}
$$

The timing is as in Figure 1.

\subsection{First best effort}

We present as a benchmark the first-best level of effort. Political benefits are not included in social welfare. When a politician wins an election social welfare does not increase; but he simply gets the votes instead of another politician. Similarly part of the cost of transfer $D(T)$ is political: the remaining social cost of transfer is $d(T)$. First-best effort can be found from

$$
\begin{gathered}
\underset{e_{1}, e_{2}, w_{1}, w_{2}}{\operatorname{Max}} v_{1}+v_{2}+\beta v_{1}+\beta v_{2}-c\left(e_{1}\right)-c\left(e_{2}\right)-d\left(w_{1}+w_{2}\right) \\
\text { s.t. } w_{i}+\beta v_{i}-c\left(e_{i}\right) \geq 0 \text { for } i=1,2 .
\end{gathered}
$$

The first-order condition is

$$
(1+\beta) \Delta v p^{\prime}\left(e_{i}^{*}\right)=c^{\prime}\left(e_{i}^{*}\right)
$$

if and only if $\beta v_{i}\left(e_{i}^{*}\right)-c\left(e_{i}^{*}\right) \geq 0$; otherwise,

$$
(1+\beta) \Delta v p^{\prime}\left(e_{i}^{*}\right)=c^{\prime}\left(e_{i}^{*}\right)+d^{\prime}\left(\sum c\left(e_{i}^{*}\right)-\sum \beta v_{i}\left(e_{i}^{*}\right)\right) .
$$

If private benefits are sufficient to motivate the manager to participate, social welfare maximising effort is given by (1). Then the marginal cost of effort is set equal to the marginal benefit from higher value service and higher private benefits. If the manager needs a monetary wage to motivate him to participate, the first-best effort is given by (2). Then the marginal social cost of raising taxes to compensate the manager has to be included in costs. 


\section{The Alternative Forms of Organisation}

In this section we characterise each of the four forms of organisation that can be chosen by the politician.

\subsection{No Competition and Political Control}

Effort and the value of service are noncontractible, so under no competition there is nothing contractible to which incentives could be related. Thus exante contracts cannot provide incentives. Neither does ex-post bargaining, since once effort is made its value is sunk. $\mathrm{M}$ can therefore be fired by $\mathrm{P}$ at no cost and $\mathrm{M}$ will receive a zero payoff from ex-post bargaining. When the suppliers do not compete, the manager chooses an effort level that maximises his private benefit minus the effort cost

$$
\operatorname{Max} \alpha_{M} \beta v_{i}-c\left(e_{i}\right) \text {. }
$$

The first-order condition gives the optimal effort level $e_{i}^{N P}$, where superscript NP refers to no competition and political control:

$$
\alpha_{M} \beta p^{\prime}\left(e_{i}^{N P}\right) \Delta v-c^{\prime}\left(e_{i}^{N P}\right)=0 .
$$

Lemma $1 T^{N P}=0$.

(3) is independent of $w_{i}$.

There is no reason for $\mathrm{P}$ to pay wages to $\mathrm{M}$ since the wage does not affect effort but increases the cost for $\mathrm{P}$ and, as M's outside wage is zero, his individual rationality constraint is satisfied for $w_{i}=0$. When $\mathrm{P}$ has control rights he will choose a zero wage, and accordingly taxes are zero. P's utility is

$$
U^{N P}=\rho \sum v_{i}\left(e_{i}^{N P}\right)-D(0)
$$

\subsection{No Competition and Managerial Control}

If $\mathrm{M}$ has the control rights, he would like to increase $w_{i}$ but where there is no competition all the supplier's income comes directly from P. P knows that M would spend all the budget on wages and that this wage would not make M 
work any harder. Thus $\mathrm{P}$ gives $\mathrm{M}$ a zero budget. But as $\mathrm{M}$ receives a higher private benefit when he has control rights his problem is to

$$
\operatorname{Max} \beta v_{i}-c\left(e_{i}\right)
$$

M's effort is determined by

$$
\beta p_{i}{ }^{\prime}\left(e_{i}^{N M}\right) \Delta v-c^{\prime}\left(e_{i}^{N M}\right)=0,
$$

where superscript NM refers to no competition and managerial control.

Comparing equations (3) and (5), $e_{i}^{N M} \geq e_{i}^{N P}$. M exerts higher effort when he has the control rights and gets the full credit from the quality. Lemma 2 summarises this organisational form.

Lemma 2 (i) $T^{N M}=0$;

(ii) $e_{i}^{N M} \geq e_{i}^{N P}$.

Under $\mathrm{M}$ control $\mathrm{P}$ does not get the full credit from the provision of the service, and P's utility is

$$
U^{N M}=\alpha_{P} \rho \sum v_{i}\left(e_{i}^{N M}\right)-D(0) .
$$

\subsection{Competition and Managerial Control}

When the manager has control rights and there is competition, he chooses wages and effort to maximise his own utility subject to a no-loss constraint:

$$
\operatorname{Max} w_{i}+\beta v_{i}-c\left(e_{i}\right) \text { s.t. } R_{i}\left(e_{i}, e_{j}\right)-w_{i} \geq 0
$$

where $R_{i}\left(e_{i}, e_{j}\right)$ is the supplier's expected revenues ${ }^{5} . R_{i}\left(e_{i}, e_{j}\right)$ are determined as follows:

$$
\begin{aligned}
R_{i}\left(e_{i}, e_{j}\right) & =\lambda \frac{1}{2} v_{i}+(1-\lambda) p\left(e_{i}\right)\left(1-p\left(e_{j}\right)\right) \Delta v \\
& =\lambda \frac{1}{2}\left[\underline{v}+p\left(e_{i}\right) \Delta v\right]+(1-\lambda) p\left(e_{i}\right)\left(1-p\left(e_{j}\right)\right) \Delta v .
\end{aligned}
$$

The derivation of revenues in (7) is as follows. With probability $\lambda$ two units are required, and there is no competition between the two managers (they

\footnotetext{
${ }^{5}$ Each manager runs only one supplier, so a supplier is synonymous with a manager.
} 
can each supply only one unit). Each deal is a separate bargain in which there is a 50:50 split of the gross surplus. Each supplier's profits are therefore $\frac{1}{2} v_{i}$. If only one unit is required then the managers compete. Bargaining is under symmetric information (though the values are not verifiable), and therefore we get an efficient outcome: the higher value service is provided. If only one supplier $\mathrm{M}_{i}$ has a high value (which happens with probability $p_{i}\left(1-p_{j}\right)$ ), then $\mathrm{M}_{i}$ wins the deal. $\mathrm{P}$ bargains with $\mathrm{M}_{i}$ and has an outside option to buy the low-value service from $\mathrm{M}_{j} . \mathrm{M}_{j}$ would be willing to offer a surplus up to $\underline{v}$ to P. We assume that the quality difference is not too large (i.e. $\underline{v} \geqq \frac{\bar{v}}{2}$ ), and therefore P's outside option is binding. This leads to a division of surplus where $\mathrm{P}$ gets her outside option $\underline{v}$ and $\mathrm{M}_{i}$ gets the rest of the surplus $\Delta v$. If the service of both suppliers has the same value, all the surplus goes to P. ${ }^{6}$

When $\mathrm{M}$ has the right to choose his wages, he becomes a residual claimant. $\mathrm{M}$ spends all the surplus on wages and the no loss constraint is always binding. Thus $\mathrm{M}$ chooses $e_{i}$ to

$$
\operatorname{Max} R_{i}\left(e_{i}, e_{j}\right)+\beta v_{i}-c\left(e_{i}\right) .
$$

The Nash equilibrium in efforts $\left(e_{1}^{C M}, e_{2}^{C M}\right)$ is determined by the following first order conditions. Superscript CM refers to competition and managerial control:

$$
\frac{\partial R_{i}\left(e_{i}^{C M}, e_{j}^{C M}\right)}{\partial e_{i}}+\beta p^{\prime}\left(e_{i}^{C M}\right) \Delta v-c^{\prime}\left(e_{i}^{C M}\right)=0 i=1,2
$$

Comparing (8) and (5) it follows that $e_{i}^{C M}>e_{i}^{N M}$; competition provides additional incentives for the manager. Higher effort not only increases private benefits but also the monetary wage. These monetary incentives make M work harder. ${ }^{7}$

\footnotetext{
${ }^{6}$ For example if both managers have high value, $\mathrm{P}$ is indifferent between the two. Say $\mathrm{P}$ chooses to bargain with $\mathrm{M}_{1}$. $\mathrm{P}^{\prime} \mathrm{s}$ outside option is to buy from $\mathrm{M}_{2}$ who is willing to offer a surplus up to $\bar{v}$ to get the deal, so $\mathrm{P}$ has to get the same from the deal with $\mathrm{M}_{1}$ : in other words $\mathrm{P}$ receives all the surplus.

${ }^{7}$ Note that although $\mathrm{M}$ is the residual claimant, it does not follow that he undertakes first-best effort. He chooses an effort level lower than first best since in the state where demand is two units the value is shared 50:50 in bargaining. His effort level may have even less to do with the level $\mathrm{P}$ would prefer. $\mathrm{P}$ is not a social welfare maximiser and may wish to implement a higher or lower level of effort.
} 
The transfers are equal to the sum of the suppliers' revenues $T=\sum R_{i}\left(e_{i}, e_{j}\right)$. $\mathrm{P}$ has to raise taxes to pay for the services, and how much he has to pay is determined by competition between the suppliers.

Lemma 3 states the main results for competition and managerial control.

Lemma $3(i) T^{C M}=\sum R_{i}\left(e_{i}^{C M}, e_{j}^{C M}\right)$;

(ii) $e_{i}^{C M}>e_{i}^{N M}$.

P's utility is

$$
U^{C M}=\alpha_{P} \rho \sum v_{i}\left(e_{i}^{C M}\right)-D\left(\sum R_{i}\left(e_{i}^{C M}, e_{j}^{C M}\right)\right) .
$$

Relative to no competition the value of the service is higher, but so are the transfers.

\subsection{Competition and Political Control}

Under political control $\mathrm{P}$ designs an incentive scheme for $\mathrm{M}$. P does not, however, directly pay the wage; instead it is paid from the revenues received by the supplier. Competition creates verifiable revenues on which $\mathrm{P}$ can base the incentive scheme. $\mathrm{P}$ can implement any effort level that satisfies the individual rationality constraint

$$
R_{i}\left(e_{i}, e_{j}\right)+\alpha_{M} \beta v_{i}-c\left(e_{i}\right) \geq 0 .
$$

This can be done by a simple linear incentive scheme or by more complex incentive schemes. We concentrate our analysis on the maximum effort level that $\mathrm{P}$ can implement, which is given by the maximal solution to

$$
R_{i}\left(e_{i}, e_{j}\right)+\alpha_{M} \beta v_{i}-c\left(e_{i}\right)=0 .
$$

Lemma 4 sums up the outcome of this institution.

Lemma $4(i)$ The highest effort $P$ can implement, $e_{i}^{C P}>0$, is given by

$\left[R_{i}\left(e_{i}^{C P}, e_{j}^{C P}\right)+\alpha_{M} \beta v_{i}^{C P}-c\left(e_{i}^{C P}\right)\right]=0 ;$

(ii) $T^{C P}=\sum R_{i}\left(e_{i}^{C P}, e_{j}^{C P}\right)$.

P's utility is

$$
U^{C P}=\rho \sum v_{i}\left(e_{i}^{C P}\right)-D\left(\sum R_{i}\left(e_{i}^{C P}, e_{j}^{C P}\right)\right) .
$$




\section{Optimal Organisation}

$\mathrm{P}$ chooses an organisation that maximises his utility. We first compare the organisational forms with respect to the level of effort. We know from Lemmas 2 and 3 that $e_{i}^{N P} \leq e_{i}^{N M}<e_{i}^{C M}$. Starting from politician control and no competition, delegating first control rights to the manager increases effort because, for given value of service, M's private benefit is greater when he is in control. Introducing competition further increases effort because higher effort increases suppliers' revenues and, therefore, $\mathrm{M}$ can pay himself a higher wage.

Comparison of effort under competition and $\mathrm{P}$ control is not as straightforward. Any effort level that satisfies the individual rationality constraint (10) can be implemented under P control and competition, while the incentive compatibility constraint determines the effort levels under the other organisational forms.

First, $e_{i}^{C P}$ is higher than $e_{i}^{N P}$ since $e_{i}^{N P}=\arg \max \left[\alpha_{M} \beta v_{i}-c\left(e_{i}\right)\right]$ while the maximum effort that can be implemented under competition and political control is given by $\left[R_{i}\left(e_{i}^{C P}, e_{j}^{C P}\right)+\alpha_{M} \beta v_{i}^{C P}-c\left(e_{i}^{C P}\right)\right]=0$. Effort that equates M's private benefit under $\mathrm{P}$ control to his costs, $\alpha_{M} \beta v_{i}=c\left(e_{i}\right)$, (i.e. ignoring the revenue term) is already higher than $e_{i}^{N P}$, which equates the marginal private benefit to marginal cost.

Second, compare $e_{i}^{C P}$ and $e_{i}^{C M}$. When $\alpha_{M} \rightarrow 0$ and managerial private benefits are important ( $\beta$ is high), $e_{i}^{C M}>e_{i}^{C P}$ since $e_{i}^{C M}=\arg \max \left[R_{i}\left(e_{i}, e_{j}\right)+\beta v_{i}-c\left(e_{i}\right)\right]$. Then managerial private benefits have a significant effect on $e_{i}^{C M}$ but no effect on $e_{i}^{C P}$, while when $\alpha_{M} \rightarrow 1 \mathrm{P}$ can implement $e_{i}^{C M}$ under competition and political control as M's private benefits do not depend on who has control rights.

Turning to a comparison of the level of transfers, under no competition transfers are zero and $\mathrm{P}$ does not have to raise any taxes. With competition $\mathrm{P}$ has to raise taxes equal to the two suppliers' revenues.

$\mathrm{P}$ will choose the organisational form that maximises his own utility, which depends both on the value of service (and effort) and on transfers. We can find the optimal organisation by pairwise comparisons. 


\subsection{Decentralisation}

We first analyse decentralisation: whether or not to give control rights to the manager. $\mathrm{P}$ will not delegate control rights under no competition if and only if

$$
\rho \sum v_{i}\left(e_{i}^{N P}\right) \geq \alpha_{P} \rho \sum v_{i}\left(e_{i}^{N M}\right) .
$$

Under no competition transfers are equal to zero: the choice of organisation depends only on the political benefits. The value of the service is higher under $\mathrm{M}$ control $\left(e_{i}^{N M} \geq e_{i}^{N P}\right)$, but $\mathrm{P}$ does not get the full credit for it. When $\frac{\alpha_{P}}{\alpha_{M}}$ is low P's utility is higher when he keeps the control rights. High $\alpha_{M}$ means that M's effort is not much lower under $\mathrm{P}$ control while low $\alpha_{P}$ means that $\mathrm{P}$ does not get enough credit for the higher value service under $\mathrm{M}$ control to make delegation worthwhile. Conversely, for high $\frac{\alpha_{P}}{\alpha_{M}} \mathrm{P}$ will delegate as he gets enough credit for the significantly higher value service under M control.

For the decentralisation decision under competition, $\mathrm{P}$ keeps the control rights if and only if

$\rho \sum v_{i}\left(e_{i}^{C P}\right)-D\left(\sum R_{i}\left(e_{i}^{C P}, e_{j}^{C P}\right)\right) \geq \alpha_{P} \rho \sum v_{i}\left(e_{i}^{C M}\right)-D\left(\sum R_{i}\left(e_{i}^{C M}, e_{j}^{C M}\right)\right)$.

The analysis is more complex than in the no competition case, but the result is the same: $\mathrm{P}$ keeps the control rights when $\frac{\alpha_{P}}{\alpha_{M}}$ is low and delegates otherwise, just as under no competition.

Proposition 1 The higher is $\frac{\alpha_{P}}{\alpha_{M}}$ the more beneficial it is to the politician to delegate control rights to the managers (i.e. to decentralise).

Proof. Available on JEBP website

$\frac{\alpha_{P}}{\alpha_{M}}$ is one of the key forces in our model. It can be seen as a measure of the loss from devolving decision making to the manager: the higher this ratio, the lower the loss to the politician of managerial control. When this relative loss from delegation is low the politician will delegate control rights to the managers. 


\subsection{Competition}

We now consider the decision whether to introduce competition. Competition increases the value of the service, as $e_{i}^{C P}>e_{i}^{N P}$ and $e_{i}^{C M}>e_{i}^{N M}$, but also increases taxes. $\mathrm{P}$ will introduce competition when the higher political benefits outweigh the higher political costs. Under $\mathrm{P}$ control competition dominates if and only if

$$
\rho\left[\sum v_{i}\left(e_{i}^{C P}\right)-\sum v_{i}\left(e_{i}^{N P}\right)\right] \geq D\left(\sum R_{i}\left(e_{i}^{C P}, e_{j}^{C P}\right)\right) .
$$

Under $\mathrm{M}$ control $\mathrm{P}$ introduces competition if and only if

$$
\alpha_{P} \rho\left[\sum v_{i}\left(e_{i}^{C M}\right)-\sum v_{i}\left(e_{i}^{N M}\right)\right] \geq D\left(\sum R_{i}\left(e_{i}^{C M}, e_{j}^{C M}\right)\right) .
$$

$\mathrm{P}$ would never introduce competition if his utility were maximised with either $e_{i}^{N P}$ or $e_{i}^{N M}$ (the efforts that are achievable at no cost under no competition). $\mathrm{P}$ can implement a higher level of effort under competition, but that will increase the political costs as well. Accordingly, competition dominates when political benefits are high relative to political costs $\left(\frac{D(\cdot)}{P(\cdot)}\right.$ is low). This is true whoever has the control rights. It is also true where competition and $\mathrm{M}$ control is dominated ${ }^{8}$ and $\mathrm{P}$ compares $\mathrm{CP}$ and $\mathrm{NM}$ :

$$
\rho\left[\sum v_{i}\left(e_{i}^{C P}\right)-\alpha_{P} \sum v_{i}\left(e_{i}^{N M}\right)\right] \geq D\left(\sum R_{i}\left(e_{i}^{C P}, e_{j}^{C P}\right)\right) .
$$

This gives our second Proposition.

Proposition 2 The lower is $\frac{D(\cdot)}{P(\cdot)}$, the more beneficial it is to the politician to introduce competition.

This key term can be given the following interpretation. Governments raise taxes to supply a number of services. At any one time, these services may differ in popularity. So, for example, the provision of health and education services by government often has considerable political support, while the provision of social security is viewed as a necessary but unpopular government activity. Provision of the first type of services may give politicians

\footnotetext{
${ }^{8}$ If $e_{i}^{C M}<e_{i}^{C P}$ (which holds for $\alpha_{M}$ large), $\mathrm{P}$ can get a higher value service under his control and get all the credit from it. Then CM is dominated by CP.
} 
greater benefit than provision of the second type, whilst raising taxes for unpopular services may be more costly for a politician. $\frac{D(\cdot)}{P(\cdot)}$ can thus be seen as a measure of the relative unpopularity of the service: the higher this ratio the less popular the service. With this interpretation we have a result for optimal form of organisation for services of different popularity. The politician is less likely to choose competition for unpopular services as competition is associated with higher transfer, but more likely to introduce competition for popular services.

\subsection{Interaction of Decentralisation and Competition}

$\mathrm{P}$ delegates control rights when $\frac{\alpha_{P}}{\alpha_{M}}$ is high and introduces competition when $\frac{D(\cdot)}{P(\cdot)}$ is low. We now analyse the interaction of competition and control rights. How does the popularity of the service affect the decentralisation decision, and how does the loss from devolving decision making to the manager affect P's choice to introduce competition. To answer these questions we have to locate the boundary between the different organisational forms.

First, the boundary between $\mathrm{M}$ and $\mathrm{P}$ control with no competition is defined by

$$
\rho\left[\sum v_{i}\left(e_{i}^{N P}\right)-\alpha_{P} \sum v_{i}\left(e_{i}^{N M}\right)\right]=0 .
$$

Since (17) is linear in $\rho, \rho$ has no effect on the boundary. On the boundary higher political benefits increase P's utility equally under $\mathrm{P}$ and $\mathrm{M}$ control. $\mathrm{P}$ 's decision to delegate control rights under no competition depends only on $\frac{\alpha_{P}}{\alpha_{M}}$. This is depicted by the vertical boundary between NP and NM in Figure 2 .

Second, consider the boundary between $\mathrm{M}$ and $\mathrm{P}$ control under competition:

$\rho\left[\alpha_{P} \sum v_{i}\left(e_{i}^{C M}\right)-\sum v_{i}\left(e_{i}^{C P}\right)\right]=D\left(\sum R_{i}\left(e_{i}^{C M}, e_{j}^{C M}\right)\right)-D\left(\sum R_{i}\left(e_{i}^{C P}, e_{j}^{C P}\right)\right)>0$.

First, this boundary exists only if $\alpha_{M}$ is small enough since only then is $e_{i}^{C M}>e_{i}^{C P}$. Since $\mathrm{P}$ only would delegate control rights if there were no other way to motivate the manager to higher effort, it follows that on the boundary 
both political benefits and costs are higher under $\mathrm{M}$ control. Then consider the effect of higher political benefits on the boundary. Differentiating the left-hand-side of (18) with respect to $\rho$ we obtain

$$
\alpha_{P} \sum v_{i}\left(e_{i}^{C M}\right)-\sum v_{i}\left(e_{i}^{C P}\right)>0 .
$$

(19) is positive from equation (18). Political benefits increase more under managerial control. Since political costs do not depend on $\rho$, increasing $\rho$ makes managerial control strictly better. Therefore the more popular the service is, the lower is the critical value of $\frac{\alpha_{P}}{\alpha_{M}}$ that makes decentralisation optimal for P.

In summary, the boundary between political and managerial control is vertical under no competition: once $\frac{D(\cdot)}{P(\cdot)}$ is high enough, there is no trade-off between service popularity and delegation of control rights. Under competition (where $\frac{D(\cdot)}{P(\cdot)}$ is lower) a trade-off exists. This upward sloping boundary between politician control rights and managerial control rights under competition can be interpreted as follows. If a service is very popular, the politician will be willing to give up political control rights in order to increase managerial effort and the value of the service. This is because the cost of raising taxes for this service is low relative to the benefits derived from the effort.

Now consider the boundary between competition and no competition. We know that competition will be introduced for low $\frac{D(\cdot)}{P(\cdot)}$. How does this decision depend on $\frac{\alpha_{P}}{\alpha_{M}}$ ? Under $\mathrm{P}$ control the boundary is defined by

$$
\rho\left[\sum v_{i}\left(e_{i}^{C P}\right)-\sum v_{i}\left(e_{i}^{N P}\right)\right]=D\left(\sum R_{i}\left(e_{i}^{C P}, e_{j}^{C P}\right)\right) .
$$

As $\mathrm{P}$ has the control rights this comparison does not depend on the parameter $\alpha_{P}$. Both $e_{i}^{N P}$ and $e_{i}^{C P}$ are increasing in $\alpha_{M}: e_{i}^{N P}$ because M's marginal private benefit increases and $e_{i}^{C P}$ because the individual rationality constraint is relaxed. However, it is ambiguous which effort increases more. We have drawn Figure 2 assuming this boundary is increasing. ${ }^{9}$

Finally, we analyse the boundary between competition and no competition under managerial control. The two regimes give the same utility for $\mathrm{P}$ when

$$
\alpha_{P} \rho\left[\sum v\left(e_{i}^{C M}\right)-\sum v\left(e_{i}^{N M}\right)\right]=D\left(\sum R\left(e_{i}^{C M}\right)\right)
$$

\footnotetext{
${ }^{9}$ With the specific functional forms introduced in Section 6 , the CP-NP boundary is increasing when competition effect is high.
} 
holds. Since $\mathrm{M}$ has the control rights this expression does not depend on $\alpha_{M}$. Differentiating the left-hand-side of (21) with respect to $\alpha_{P}$ we obtain

$$
\rho\left[\sum v\left(e_{i}^{C M}\right)-\sum v\left(e_{i}^{N M}\right)\right]>0 .
$$

Equation (22) is positive since $e_{i}^{C M}>e_{i}^{N M}$. Therefore starting from the boundary and increasing $\frac{\alpha_{P}}{\alpha_{M}}$ makes competition strictly better for P. To restore equality requires higher $\frac{D(\cdot)}{P(\cdot)}$. The lower the loss from devolving decision making to the manager, the less popular can the service be and competition can still be introduced.

Figure 2 summarises the results. The trade-offs between the two forces can be seen in the boundaries between the various types of organisation. In Figure 2 the boundary between competition and no competition is increasing in $\frac{\alpha_{P}}{\alpha_{M}}$ and $\frac{D(\cdot)}{P(\cdot)}$, indicating that the tendency to switch to no-competition as $\frac{D(\cdot)}{P(\cdot)}$ increases can be offset by a fall in the loss from devolving decision making to the manager. Put another way, the lower the loss from delegation of control rights, the greater the unpopularity of the service may be under competition.

\section{$6 \quad$ Manager's Private Benefits}

We have shown the importance of the key parameters, $\frac{\alpha_{P}}{\alpha_{M}}$ and $\frac{D(\cdot)}{P(\cdot)}$, in determining the choice of organisation. In this section we analyse how an increase in the manager's private benefit, $\beta$, changes the optimal organisational form. We introduce the following specific functional forms to undertake this analysis: $p\left(e_{i}\right)=p e_{i}, c\left(e_{i}\right)=\frac{1}{2} e_{i}^{2}$ and $D(T)=T^{\gamma}$ where $\gamma \geq \underline{\gamma}$ and $\underline{\gamma}>1$.

\subsection{Competition}

We first analyse how an increase in $\beta$ affects $\mathrm{P}$ 's decision to introduce competition. Each boundary is examined in detail in the Appendix, and we draw our results together here.

One would expect that competition becomes less likely as private benefits on their own motivate more. It is not necessary for $\mathrm{P}$ to introduce costly competition to improve the value of the service when private benefits alone motivate more. However, we show that the effect of higher managerial private 
benefits is more subtle: competition can actually become more likely on some parts of the boundary between competition and no competition.

We first examine the effect of higher $\beta$ on the CM-NM boundary. When M's marginal private benefit increases, $M$ exerts more effort. But under competition this effect is dampened by the fact that the rival supplier's effort is also increased, reducing the marginal monetary return to effort $\left(\partial^{2} R / \partial e_{i} \partial e_{j}<0\right)$. This is why M's effort is more responsive to higher private benefits under no competition, and accordingly the CM-NM boundary shifts in favour of NM. In other words, competition becomes less likely.

The CP-NP (or CP-NM) boundary can move either way. Under CP organisation, $\mathrm{P}$ implements an effort level that equates the supplier's revenues plus M's private benefits to M's effort costs. When $\beta$ increases, M's private benefits increase for a given effort level, and $\mathrm{P}$ can then push for higher effort, without violating the individual rationality constraint. But this effect as well is dampened by the rival supplier's increased effort which reduces the supplier's revenues. This "competition effect" is $\frac{\partial R_{i}}{\partial e_{j}}=-(1-\lambda) p^{2} \Delta v e_{i}$. Our analysis shows that the effect of an increase in $\beta$ depends importantly on whether

$$
(1-\lambda) p^{2} \Delta v \geq \frac{1}{2}
$$

holds or not. This competition effect depends on three features of our model. The first is the probability that the suppliers actually compete, $(1-\lambda)$. The second is the size of the the winner's surplus under competition, $\Delta v{ }^{10}$ The third is the probability with which effort translates into higher quality, $p$, as the extent to which the rival's higher effort reduces the probability that the supplier is the only supplier with high quality depends on $p$.

When (23) holds, the competition effect is large and effort increases relatively little under $\mathrm{CP}$ as a response to higher $\beta$. Then M's effort is more responsive to $\beta$ under no competition and competition becomes less likely, just as on the CM-NM boundary. Part $(i)$ of the following Proposition states this result.

Proposition 3 When $\beta$ increases

(i) competition becomes less likely if $(1-\lambda) p^{2} \Delta v \geq \frac{1}{2}$, and

\footnotetext{
${ }^{10}$ The only case when the supplier earns positive revenues under competition is when there is one supplier with high quality service and another with low quality service.
} 
(ii) CP becomes more likely if $(1-\lambda) p^{2} \Delta v<\frac{\alpha_{M}}{\alpha_{P}}-\frac{1}{2}$ and $\rho$ is high enough on the CP boundary.

Proof. In the Appendix.

Part (ii) of Proposition 3 gives the surprising result. When private benefits increase, $\mathrm{M}$ provides a higher quality service under no competition at no cost to the politician. But quality increases more under competition (if the competition effect is low ${ }^{11}$ ) and although also the political costs increase (while they remain zero under no competition), the dominant effect is the higher political benefits under CP (when $\rho$ is high enough). This is the case where $\mathrm{P}$ is more likely to introduce competition when $\beta$ increases.

\subsection{Decentralisation}

We will now examine how an increase in $\beta$ affects P's decision to decentralise control rights. One might think that since M's control rights are related to his private benefits, higher private benefits would make delegation a better instrument for increasing the value of the service. However, our results show that higher $\beta$ does not necessarily lead to more decentralisation. Under no competition $\beta$ does not have any effect on $\mathrm{P}$ 's decision to delegate, while under competition the effect can go either way. Our results are given in the following Proposition.

Proposition 4 When $\beta$ increases

(i) the NM-NP boundary does not shift, and

(ii) managerial control becomes more likely on the CM-CP boundary if and only if $\frac{\alpha_{P}}{\alpha_{M}}>\frac{2\left[(1-\lambda) p^{2} \Delta v+1\right]}{2(1-\lambda) p^{2} \Delta v+1}$ and $\rho$ is high enough on the boundary.

Proof. In the Appendix.

Under no competition P's decision to decentralise does not depend at all on M's private benefits. Although the effort increases more under NM

\footnotetext{
${ }^{11}$ Proposition 3 (ii) also requires $\frac{\alpha_{P}}{\alpha_{M}}$ to be low enough. This is because when we compare $\mathrm{CP}$ and NM the control rights also differ. When $\alpha_{P}$ is low political benefits do not increase much under NM since $\mathrm{P}$ does not get much credit for the better service. For high $\alpha_{M}$ effort responds a lot to higher private benefits under $\mathrm{CP}$ since the private benefits are a significant motivator for $\mathrm{M}$ even under $\mathrm{P}$ control. Furthermore $\mathrm{P}$ gets all the credit for the improved service. Therefore the political benefits increase more under CP compared to NM when $\frac{\alpha_{P}}{\alpha_{M}}-$ and $(1-\lambda) p^{2} \Delta v-$ are low.
} 
$\left(\frac{\partial e^{N P}}{\partial \beta}<\frac{\partial e^{N M}}{\partial \beta}\right) \mathrm{P}$ gets less credit from it. These two effects cancel out on the NM-NP boundary.

Under competition, managerial control becomes more likely if the loss from devolving decision making is small enough and the political benefits are high enough. First, political benefits increase more under CM if $\frac{\alpha_{P}}{\alpha_{M}}$ is high. If $\alpha_{M}$ is low, effort does not respond much to higher private benefits under CP because private benefits are not a significant motivator, and if $\alpha_{P}$ is high, $\mathrm{P}$ gets enough credit for the value improvement under $\mathrm{CM}$ and accordingly political benefits increase more under CM. Second, political costs increase more under CM, ${ }^{12}$ but when $\rho$ is high enough, political benefits increase more than the political costs and $\mathrm{P}$ is more likely to delegate control rights when $\beta$ increases.

However it is also possible that higher private benefits result in less delegation. This is the case when the greater increase in the value of the service under $\mathrm{M}$ control is politically too costly ( $\rho$ is low). Alternatively, when $\frac{\alpha_{P}}{\alpha_{M}}$ is low, effort and the value of the service increases less under M control. This is because when $\alpha_{M}$ is high, private benefits motivate well even under $\mathrm{P}$ control and effort actually increases more under CP. Then $\mathrm{P}$ is less likely to delegate control rights when $\beta$ increases.

This analysis shows that what drives our model are the two key ratios, $\rho$ (which, in turn, determines $\left.\frac{D(\cdot)}{P(\cdot)}\right)$ and $\frac{\alpha_{P}}{\alpha_{M}}$, and the competition effect. This section also shows that the results can be quite subtle. While the intuition behind $\frac{D(\cdot)}{P(\cdot)}$ and $\frac{\alpha_{P}}{\alpha_{M}}$ is straightforward, our results show that what might seem obvious (that increasing the private benefit managers get from service provision should reduce the need for competition) does not necessarily hold. Neither is it always true that higher private benefits make delegation more powerful but the effect can go either way, or there is even no effect (under no competition). This complexity of the model also extends to analysis of other key parameters; for example, the gap in quality between a low and a high quality supplier.

\footnotetext{
${ }^{12}$ This is because $e_{i}^{C M}>e_{i}^{C P}$ on the CM-CP boundary (as $\mathrm{P}$ would not delegate control rights if he could achieve the same effort level under his control). Since the political costs are convex, marginal political cost is higher under CM. Furthermore $\frac{\partial e_{i}^{C M}}{\partial \beta}>\frac{\partial e_{i}^{C P}}{\partial \beta}$ as explained above. Therefore the political costs clearly increase more under CM when $\beta$ increases.
} 


\section{Conclusion}

This paper examines politician choice of organisational form for government services where the service remains government funded but the politician has the choice of delegation of control rights to managers and the introduction of competition in supply. We analyse the case of a service that has an observable but non-contractible value for the end users and for which both the producer of the service and the politician derive additional, also noncontractible, private benefits from its production. We show that the choice of organisational form will depend upon two ratios. The first is the ratio of political benefit of service provision to the political cost of raising taxes. The second is the ratio of political benefit lost under managerial control rights to managerial private benefits lost under politician control rights. Where the former is low, the politician is less likely to introduce competition. Where the latter is high, the politician is more likely to delegate control rights to a manager. Further, these factors are not independent. At the margin there is a trade-off between these two forces, which means that the politician may choose to have managerial control under competition with a higher loss from delegation than under no competition. While these factors are intuitive, our analysis also shows that delegation is not always optimal when the supplier gets more private benefit from service provision, and competition may be introduced even when managers have strong private incentives to supply high quality services.

Our emphasis on the politician as self-interested as distinct from a social welfare maximiser seems to us to be helpful in understanding why changes in organisational form of the public sector arise. One corollary of our model is that services that are 'popular' are more likely to be produced under competition, and the smaller the political loss from delegation of control rights, the more likely is managerial control. We would therefore expect to see the introduction of internal markets in services that are 'popular' and for which the costs of not giving managers control right is high. On the other hand, we would expect to see a single agency rather than competition where services are less popular, and there are similar political losses from delegation of control rights. This appears to mirror the patterns in recent UK welfare state reform. Services in which professionals play a large role in service delivery (for which managerial control may be seen to have large advantages) have been associated with a movement of control rights from politicians to managers. Competition has been introduced in those services that receive 
relatively high political support (for example, education and health), whilst those where the general level of political support is lower have been devolved to free standing but non-competing public sector agencies (for example, the Child Support Agency or the Highways Agency). 


\section{References}

Besley, T., Ghatak, M., 2005. Competition and incentives with motivated agents. American Economic Review 95, 616-636.

Boycko, M., Shleifer, A., Vishny, R., 1996. A theory of privatisation. Economic Journal 106, 309-319.

Francois, P., 2000. 'Public service motivation' as an argument for government provision. Journal of Public Economics 78, 275-299.

Hart, O., Shleifer, A.,Vishny, R., 1997. The proper scope of government: Theory and an application to prisons. Quarterly Journal of Economics 112, 1127-1161.

Le Grand, J., Bartlett, W., 1993. Quasi-Markets and Social Policy. London: MacMillan.

Le Grand, J., 1991. Quasi-markets and social policy. Economic Journal 101, 1256-67.

Propper, C., 1996. Market structure and prices: the responses of NHS hospitals to competition. Journal of Public Economics 61, 307-335.

Shleifer, A., Vishny, R., 1994. Politicians and firms. Quarterly Journal of Economics 109, 996-1025.

Szymanski, S., Bello, H., 1996. Compulsory competitive tendering for public services in the UK: the case of refuse collection. Journal of Business Finance and Accounting 23, 881 - 903.

Tirole, J., 1994. The internal organization of government. Oxford Economic Papers 46, 1-26. 
Table 1

\begin{tabular}{|l|l|l|}
\hline & Competition & No competition \\
\hline $\begin{array}{l}\text { Managerial Control } \\
\text { Rights }\end{array}$ & Quasi-markets & Single agency \\
\hline Politician Control Rights & & $\begin{array}{l}\text { Central government } \\
\text { department }\end{array}$ \\
\hline
\end{tabular}


Figure 1: Time line

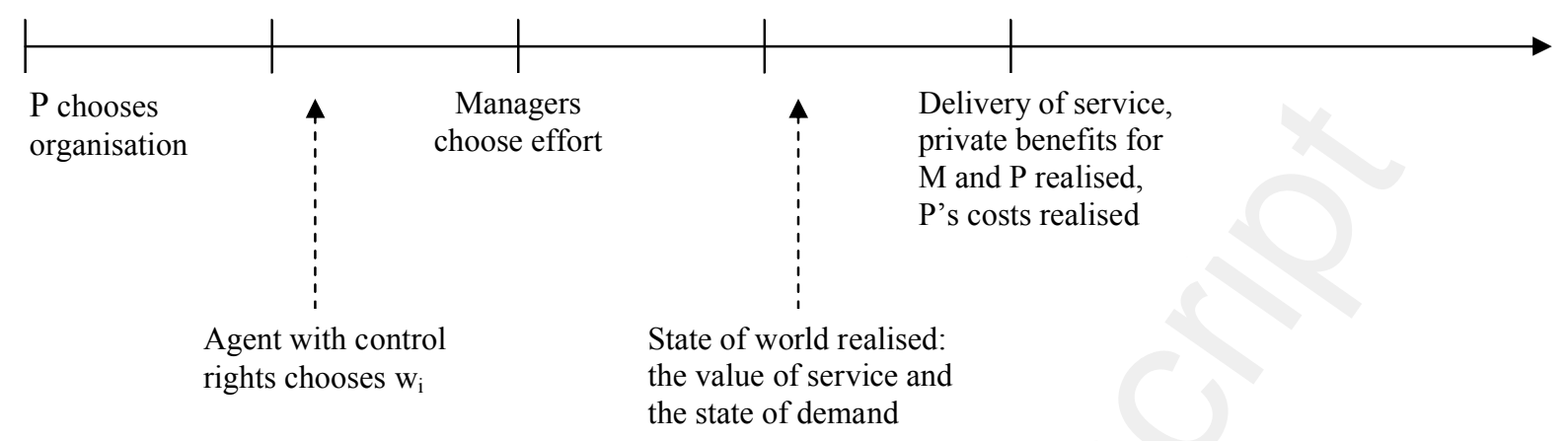

Figure 2: Optimal form of organisation

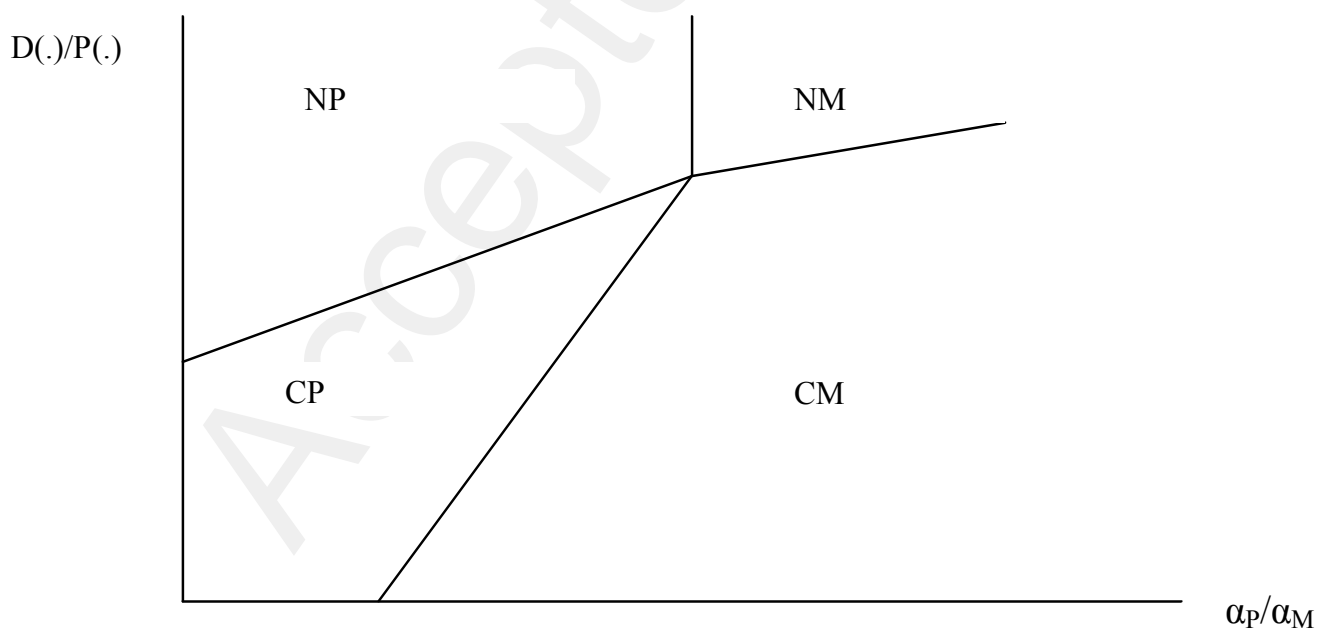

$\mathrm{N}=$ no competition, $\mathrm{C}=$ competition, $\mathrm{P}=$ politician control rights, $\mathrm{M}=$ managerial control rights 